\title{
Evaluation of the Performance of Creative Arts Teachers of Cape Coast Metropolitan Kindergarten Schools
}

\author{
Stephen Owusu-Ansah, \\ Tutor, Vocational Skills Department, OLA College of Education, Cape Coast-Ghana.
}

\begin{abstract}
The purpose of the study was to evaluate the performance of creative Arts Teachers of Cape Coast Metropolitan Kindergarten Schools. The research design adopted for this study is the descriptive survey. Twenty-two (22) teachers and ten (10) head teachers totalling thirty-two (32) were used for the study. Questionnaire and observation were the instruments used for the study. It was found out that teachers have the necessary creative art skills and new knowledge pupils need to acquire. It was also found out that although the KG schools in the Cape Coast Metropolis have teaching and learning materials, the materials are not in suitable conditions. It was recommended that teaching and learning materials must be kept in a suitable condition.
\end{abstract}

Key word: In-service Training, Kindergarten, Pre-school, Motivation

\section{Introduction}

Generally, education aims at developing the intellectual, moral, social and physical characteristics of individuals, so that they will be able to enjoy living as people, support themselves adequately as adults, and contribute sufficiently to nation-building. But Ghana has not realized this philosophy to the full since the type of education introduced and practiced in the nation did not possess the components to equip learners with the requisite knowledge and skills capable of functioning effectively as Ghanaians, and for that matter Africans. The educated people rather looked up to foreign cultures and white collar jobs which are not in existence, and some get confused because the curricula are Europeanized having little to do with Ghanaian culture. In like manner, the westerners imposed their arts on Africans, and for that matter, Ghana, therefore what the learners acquired were not applicable to their local situation.

After series of considerations, the Pragmatist and Re-constructionist philosophies were adopted by Ghanaians through which came the need for the design of the new structure and content of education. This brought into existence the present 63-3-4 education system. This reform has the view of preparing pupils to be practical oriented and analytical enough to face their own problems and those of the nation squarely in this global world and technological era. The education system was structured to meet the needs of the individual, the society in which he lives and the nation as a whole. Hence the need to study the creative arts programme after running over 5 years

Art exist in all societies and has been created by human beings since prehistoric times. Dissamayake (1995) cited in Koster (1997) points out that art creation is taking ordinary things and making them special. She argues that making art is part of being human and is a normal behaviour in which all people participate.

In the same way, art is a part of every activity we offer children. It is there in the box of blocks we give them to use, it is in the picture book we read to them or when we ask the child to select the red ball or blue one. The colours, textures and forms of the toys we purchase, the picture we choose to hang on wall, and the patterns on our floors all form the artistic environment of the child.

Art helps children grow cognitively by practicing numeration skills. Art supplies invite counting, sorting and classifying. Through question, children can become aware of the number concepts they use in their artwork. They can count the number of flowers they have drawn or how many blue lines they have made. Art also provides children with practice in developing skills in planning and sequencing. Well designed art activities require 
children to make their own decisions and to order their behaviour to accomplish a goal.

The subject, creative arts is one of the newly introduced subjects which is being studied at Kindergarten up to primary level. Therefore the teaching and learning of creative arts requires teacher to equip the pupils with knowledge and skills to be able to create and make things on their own. The most significant element in children's learning at school is the teacher or other skilled adult. According to Edwards et al (1988) cited in Bruce (2000) children become effective in the pursuit of their enquiries in the company of gifted teachers.

Creative arts is essential to the development of emotional, material, spiritual and intellectual life, and the reason for studying it as a subject is to develop skills and aptitudes for learning new knowledge and prepare pupils for further education and training that embrace all domains of life, however there is no doubt then that, we need to go extra mile as a nation in helping our younger generation in developing their interest in creative arts because whoever is left out in the study of this creative subject might left out in the field of education.

Preschool and kindergarten teachers play a vital role in the development of children. What children learn and experience during their early years can shape their views of themselves and the world and can affect their later success or failure in school, work, and their personal lives. Preschool, kindergarten, and basic school teachers introduce children to mathematics, language, science, and social studies. They use games, music, artwork, films, books, computers, and other tools to teach basic skills.

Preschool and kindergarten children learn mainly through play and interactive activities. Preschool teachers capitalize on children's play to further language and vocabulary development (using storytelling, rhyming games, and acting games), improve social skills (having the children work together to build a neighborhood in a sandbox), and introduce scientific and mathematical concepts (showing the children how to balance and count blocks when building a bridge or how to mix colours when painting). Thus, a less structured approach, including small-group lessons, one-onone instruction, and learning through creative activities such as art, dance, and music, is adopted to teach preschool children. Play and hands-on teaching also are used by kindergarten teachers, but academics begin to take priority in kindergarten classrooms. Letter recognition, phonics, numbers, and awareness of nature and science, introduced at the preschool level, are taught primarily in kindergarten. To buttress this point the researcher in his supervisory role as a link tutor observed that the teaching and learning of creative arts in KG schools in Cape Coast metropolis was not the best due to the absence of the use of TLMs, non professionals acting as teachers, poor classroom management and many others that the researcher perceive to be in existence. This turn of event has prompted the researcher to undertake such a study to evaluate the performance of teachers teaching creative arts in $\mathrm{K}$. G. schools in Cape Coast metropolis.

\section{Statement of the Problem}

Ever since K.G education became part of the free and compulsory universal basic education (FCUBE) structure, no comprehensive evaluation has been implemented to ascertain the impact of its institution, especially in the field of creative arts which is the backbone of every developing nation. In view of this the main problem of this study is therefore to evaluate the performance of Teachers teaching creative art in kindergarten schools in Cape Coast metropolis.

\section{Purpose of the Study}

The purpose of the study was to evaluate the performance of creative Arts Teachers of Cape Coast Metropolitan Kindergarten Schools.

\section{Research Questions}

1. How can creative arts be taught to equip pupils in K.G. with new knowledge and skills?

2. To what extent are teaching and learning materials and equipment in suitable conditions for general use to enhance teaching and learning?

3. How effective is the teaching of creative art practical lessons taking place in the K.G. schools?

\section{Methodology}

The research design adopted for this study is the descriptive survey. The population for the research comprised all $\mathrm{KG}$ teachers teaching creative arts and head teachers in the Cape Coast metropolis. Cape Coast was chosen because of the cluster of schools that are situated within the metropolis ranging from the kindergarten to basic level.

In all, there were four (4) teachers in Pere Planque School, two (2) in OLA Presby School, two (2) in Kakumdo M/A KG, two (2) in St Monica KG, There were also two (2) teachers in Kwegyir 
Aggrey KG School, two (2) in Catholic Jubilee KG, two (2) in St Mary KG School. Others were A. M. E. Zion KG School (2), St Francis KG School (2) and Philip Quaicoo Girls KG School (2). Therefore the total numbers of teachers and head teachers considered in the research were twenty-two (22) teachers and ten (10) head teachers. All the twentytwo (22) teachers and ten (10) head teachers totalling thirty-two were used for the survey. The number of respondents here are proportional to the number of schools involved in the study.

\section{Research Instrument}

Questionnaire and observation were used. The reasons for choosing questionnaire was that it is very effective for securing factual information about practices and conditions which the respondents are presumed to have knowledge and for enquiring into opinion and attitudes of the subjects (Babbie, 1996).

\section{Development of Instrument}

Information was obtained through the administration of questionnaires on the teaching of creative arts in KGs within the Cape Coast metropolis. The Likert scale format was used for most of the questions. A few close-ended items were also used for others. These questions were directly related to the objectives of the study. This was done to ensure content validity. The questions were scrutinized for relevance, clarity and simplicity. The questions were pooled to solicit information on how creative arts is taught with emphasis on practical work and if the teachers have helped them to understand creative arts better.

The questions also sought to find out how the creative arts teachers were providing tuition facilities for pupils in the schools. Some of the questions asked were also on teachers' opinion about how the school climate encourages the teaching and learning of creative arts. Some of the items were formulated to get information on how often teachers attend courses or workshops for upgrading as creative arts teachers. The questionnaire for the creative arts teachers and Head teachers had twenty-six (26) and twenty-two (22) items respectively. All the questions were pooled to answer the research questions.

\section{Data Collection}

\section{Administration of Questionnaires}

Before the administration of the questionnaire, the schools with the sample were visited with an introductory letter from the Department of Art
Education, University of Education, Winneba and made aware of the impending study. Copies of the introductory letter (i.e. from the Department of Art Education; UEW) were presented to the Head teachers. The purpose of the research was then explained to the heads. When the time came for the actual administration of the questionnaire, the schools were visited one by one. When permission was granted, the respondents (KG teachers and the Head teacher) were assembled at one place. The purpose and significance of the study were explained to them. The two sets of questionnaire were then distributed and the meanings of all the terms were clearly defined. Respondents were encouraged to answer the questions carefully and truthfully and do independent work. No time limit was set but because the questions were well explained, the respondents finished answering the questionnaires in good time. Barely one hour was spent in each school. The Head teacher was made to coordinate affairs while the researcher undertook her observation of the school. Since the respondents were informed before hand of the impending exercise, they were all ready for it and there was $100 \%$ retrieval of the questionnaires.

\section{Observation}

Teachers were informed in advance that their lessons would be observed so they should not panic alongside their pupils and the exercises went on smoothly. The researcher observed lessons of 5 selected teachers on different topics of the creative arts subject from different schools. The schools were Kakumdo M/A KG, St Monica KG, Kwegyir Aggrey KG, Catholic Jubilee KG and OLA Presby KG.

\section{Procedure for Data Analysis}

The data was analyzed using the research questions as guide. A research question was thoroughly dealt with before moving to another one. To enhance the identification of responses, the items were coded using numerals. The responses to the various items were statistically analyzed by the use of the Statistical Package for Software Solution (SPSS) programme which helped in creating diagrams, charts and tabulating frequencies. Frequencies for the items were computed and converted into percentages and used for the discussion.

\section{Results and Discussion}

This chapter deals with the presentation of results and discussion of the data collected. Descriptive statistics was used in presenting the results. Frequencies and percentages were employed. These 
were presented in tabular form. There is general discussion of the results at the end of each section aimed at answering the research questions.

\section{Research Question 1}

How can creative arts be taught to equip pupils in K.G. with new knowledge and skills?
The first research question was meant to find out from the teachers how creative art could be taught effectively in order to promote creativity and acquisition of new knowledge in pupils. The views of the respondents are presented in Table 1.

\section{Table 1: Teaching Creative Art to Equip Pupils with New Knowledge}

\begin{tabular}{|l|l|l|l|l|}
\hline \multirow{2}{*}{ Equipping pupils' with creative art } & \multicolumn{3}{|l|}{ Teachers } \\
\cline { 2 - 5 } & \multicolumn{2}{|l|}{ Yes } & No \\
\cline { 2 - 5 } & Freq. & \% & Freq. & \% \\
\hline $\begin{array}{l}\text { Can creative arts be taught to equip pupils with } \\
\text { new knowledge and skills? }\end{array}$ & 17 & 77.3 & 5 & 22.7 \\
\hline $\begin{array}{l}\text { Are your pupils motivated to develop their } \\
\text { creative abilities? }\end{array}$ & 18 & 81.8 & 4 & 18.2 \\
\hline $\begin{array}{l}\text { Are your pupils confident of completing their } \\
\text { assigned work? }\end{array}$ & 15 & 68.2 & 7 & 31.8 \\
\hline Do you assign group work to your pupils? & 20 & 90.9 & 2 & 9.1 \\
\hline
\end{tabular}

Table 1 shows that while $17(77.3 \%)$ teachers held that creative art can be taught to equip pupils with new knowledge, $5(22.7 \%)$ said no. Majority $(81.8 \%)$ of the respondents were also of the view that pupils are motivated to develop their own creative abilities. This was however contrary to the views of $18.2 \%$ of the respondents.

As indicated by Gaitskell et al (1982, P.28) that "art is personal and creative and for that matter people must control the activities that engaged them. It is expected that pupils be encouraged to be in control of their works". They point out that artist must have freedom to choose both their subject matter and their manner of expression. In the same way a teacher should not touch a child's work when he thinks the child is wrong. The child has his/her ideas and you have yours, and they are sure to be different. That in this case will help them develop the new knowledge expected. Otherwise if teachers insist on pupils expressions on their works, it would stifle creativity. According to Jameson (1968) the teacher should not intrude when the child is working happily and spontaneously. In addition, the teacher should develop the technique of turning the child's question round and aiming it back at him and so evoking from the child's responses which are answers to his original question.

The study also shows that while 15 (68.2\%) teachers shared the view that pupils are always confident of completing their assigned work, 7 $(31.8 \%)$ disagreed.

The teachers were also asked to indicate the kind of creative skills they would want their pupils to develop. The outcome of their views is shown in Table 2.

\section{Table 2: The Kind of Creative Skills Pupils Develop}

\begin{tabular}{|l|l|l|}
\hline \multirow{2}{*}{ Creative skills } & Teachers \\
\cline { 2 - 3 } & Freq. & \% \\
\hline Creativity & 8 & 36.4 \\
\hline Critical thinking and problem solving & 5 & 22.7 \\
\hline Integration of knowledge & 9 & 40.9 \\
\hline Total & $\mathbf{2 2}$ & $\mathbf{1 0 0}$ \\
\hline
\end{tabular}

The results from table 2 shows that while $8(36.4 \%)$ teachers indicated that their pupils acquire skills in creativity, $5(22.7 \%)$ mentioned critical thinking and problem solving skills. These teachers thus gear towards the Cognitive approach, which focuses on internal mental thinking and the process of perception as well as cognitive structures for learning and problem solving as indicated by Quansah (1997). Also, 9 (40.9\%) held that their pupils acquire skills in integration of knowledge. Though the teachers had different views of the skills people develop, Koster (2005) opines that the 
teacher is like a gardener, providing the "fertile ground", the enriched environment that gives a child a start in thinking and in working as an artist and this allows the child's creativity to flow in such creative skill such as creativity, critical thinking and problem solving as well as integration of knowledge. Lay-Dopyera and Dopyera (1992) also assert that by understanding the artistic process, teachers will be better equipped to understand how young children feel as they explore the world of art. They went on to say that children show more constructive behaviours and relationships when their teacher is warm, friendly, actively and positively involved in their activities. For effective development of creative arts skills in pupils, it is expected that teachers acquire all these skills and have all these in mind during the teaching and learning process.

\section{Research Question 2}

To what extent are teaching and learning materials and equipment in suitable conditions for general use to enhance teaching and learning?

Teaching to a large extent depends on the availability of the necessary teaching and learning resources. These resources are produced either by the teacher or the student or both and are used to facilitate the teaching and learning process. In order to enhance pupils' understanding or acquisition of knowledge, and reduce boredom, they must be presented with a wide variety of teaching and learning resources. Teaching and learning resources also help learners to form mental impression of what is being taught in the classroom. These formed the basis for formulating research question 2 . The analyses of the outcome of this research question have been presented in table 3 .

Table 3: Availability of Teaching and Learning Materials

\begin{tabular}{|c|c|c|c|c|c|c|c|c|}
\hline \multirow{3}{*}{$\begin{array}{l}\text { Availability of teaching and learning } \\
\text { materials }\end{array}$} & \multicolumn{4}{|c|}{ Head teachers } & \multicolumn{4}{|c|}{ Teachers } \\
\hline & \multicolumn{2}{|l|}{ Yes } & \multicolumn{2}{|l|}{ No } & \multicolumn{2}{|c|}{ Yes } & \multicolumn{2}{|l|}{ No } \\
\hline & Freq. & $\%$ & Freq. & $\%$ & Freq. & $\%$ & Freq. & $\%$ \\
\hline $\begin{array}{l}\text { Are teaching and learning materials } \\
\text { and equipment in suitable conditions } \\
\text { for general use? }\end{array}$ & 2 & 20 & 8 & 80 & 8 & 36.4 & 14 & 63.6 \\
\hline $\begin{array}{l}\text { Do you have the current } \mathrm{KG} \\
\text { syllabuses? }\end{array}$ & 7 & 70 & 3 & 30 & 13 & 59.1 & 9 & 40.9 \\
\hline $\begin{array}{l}\text { Are you supplied with lesson note } \\
\text { books? }\end{array}$ & 4 & 40 & 6 & 60 & 7 & 31.8 & 15 & 68.2 \\
\hline Do you prepare your lesson notes? & 0 & 0 & 0 & 0 & 22 & 100.0 & 0 & 0 \\
\hline $\begin{array}{l}\text { Does your school climate encourage } \\
\text { teaching and learning? }\end{array}$ & 8 & 80 & 2 & 20 & 19 & 86.4 & 3 & 15.6 \\
\hline $\begin{array}{l}\text { Do you receive grants for teaching this } \\
\text { programme? }\end{array}$ & 0 & 0 & 10 & 100 & 1 & 5.4 & 21 & 94.6 \\
\hline $\begin{array}{l}\text { Does the school receive any assistance } \\
\text { from any benevolent societies, both } \\
\text { home and abroad? }\end{array}$ & 4 & 40 & 6 & 60 & 18 & 81.8 & 4 & 18.2 \\
\hline $\begin{array}{l}\text { Do you appeal to parents and } \\
\text { guardians to provide their wards with } \\
\text { the necessary assistance? }\end{array}$ & 7 & 70 & 3 & 30 & 16 & 72.7 & 6 & 27.3 \\
\hline
\end{tabular}

Results from table 3 shows that while 8 (80\%) of the head teachers held that teaching and learning materials are not in suitable conditions for general use in the schools, $2(20 \%)$ disagreed. While 7 $(70 \%)$ head teachers agreed that they have the current $\mathrm{KG}$ syllabus, 3 (30\%) of them disagreed. With regard to the provision of lesson note books, the results show that while $4(40 \%)$ said "Yes", 6 $(60 \%)$ said "No." The head teachers also disagreed that the school receives assistance from the society and parents and guardians. This represents 60 per cent and 70 per cent respectively.

On the part of the teachers, while 14 (63.6\%) disagreed that teaching and learning materials in their schools are in suitable conditions, 8 (36.4\%) agreed. Contrary to the views of the head teachers, 59.1 per cent teachers held that their schools have the current KG syllabus. However, the teachers held similar views with the head teachers on the provision of lesson note books. On KG syllabus, 
$15(68 \%)$ of the teachers disagreed that their schools are provided with current KG syllabus. Majority of the teachers agreed that their schools receive assistance from the schools' communities, and parents and guardian. This was represented by $81.8 \%$ and $72.7 \%$ respectively. From the above, it is evident that TLMs are very important in the teaching and learning of creative art.

According to Stanfield (1976) when materials are in suitable conditions for general use, it plays the following roles; it reduces boredom, it focuses attention and creates interest in the class, henceforth, facilitating teaching and learning. $\mathrm{He}$ went on to say that, the kind and size of materials we should give to the child is important and worthy of note. Many adults think that small kids need small sized art materials to work with. The undeveloped conditions of the child's arm and hand muscles need to be taken into consideration. These muscles control the hand and sweep of the arm from the shoulder down to the fine movements of the hand. Little children paradoxically need larger surfaces and bold line-makers to work with in order to satisfy their inner feelings.

There is no doubt that TLM should be in the most suitable condition in order to fulfil the above roles it plays in teaching and learning of creative art.

\section{Research Question 3}

How effective is the teaching of creative art practical lessons taking place in the K.G. schools?

In order to find out whether practical lessons in creative art take place in the KG schools, research question 3 was formulated. The respondents were therefore required to answer by indicating Yes and No to the various items provided to them. The outcome of their views is presented in Table 4.

Table 4: Effective Teaching of Creative Art in KG Schools

\begin{tabular}{|c|c|c|c|c|c|c|c|c|}
\hline \multirow{3}{*}{ Effective teaching of creative art } & \multicolumn{4}{|c|}{ Head teachers } & \multicolumn{4}{|c|}{ Teachers } \\
\hline & \multicolumn{2}{|c|}{ Yes } & \multicolumn{2}{|l|}{ No } & \multicolumn{2}{|l|}{ Yes } & \multicolumn{2}{|l|}{ No } \\
\hline & Freq. & $\%$ & Freq. & $\%$ & Freq. & $\%$ & Freq. & $\%$ \\
\hline $\begin{array}{l}\text { Are effective teachings of creative art } \\
\text { practical lessons taking place at the K.G. } \\
\text { schools? }\end{array}$ & 6 & 60 & 4 & 40 & 15 & 68.2 & 7 & 31.8 \\
\hline $\begin{array}{l}\text { Do you see signs of creativity in your } \\
\text { pupils? }\end{array}$ & 7 & 70 & 3 & 30 & 14 & 63.6 & 8 & 36.4 \\
\hline $\begin{array}{l}\text { Are your pupils appreciative of their } \\
\text { performances? }\end{array}$ & 8 & 80 & 2 & 20 & 18 & 81.8 & 4 & 18.2 \\
\hline $\begin{array}{l}\text { Do pupils come out with their own ideas } \\
\text { and develop them into complete works } \\
\text { apart from works they are assigned by you? }\end{array}$ & 4 & 40 & 6 & 60 & 12 & 54.5 & 10 & 45.5 \\
\hline $\begin{array}{l}\text { Do pupils in this school perform better in } \\
\text { the long run? }\end{array}$ & 9 & 90 & 1 & 10 & 19 & 86.4 & 3 & 13.6 \\
\hline $\begin{array}{l}\text { Table } 4 \text { reveals that while } 6(60 \%) \text { and } 15 \text { ( } \\
\text { head teachers and teachers respectively he } \\
\text { effective teaching of creative art lesson take } \\
\text { in the KG schools, } 4(40 \%) \text { and } 7 \\
\text { respectively disagreed. The results also sho } \\
\text { while } 7(70 \%) \text { and } 14(63.6 \%) \text { head teache } \\
\text { teachers held that they see signs of creati } \\
\text { their pupils, } 3(30 \%) \text { and } 8(36.4 \%) \text { head te } \\
\text { and teachers disagreed. } \\
\text { The results also show that both respondents } \\
\text { similar views on how appreciative pupils } \\
\text { their performance. The results indicate that } \\
\text { ( } 80 \%) \text { and } 18 \text { ( } 81.8 \%) \text { head teachers and te } \\
\text { were in agreement, } 2 \text { (20\%) and } 4 \\
\text { disagreed. On whether pupils come out wit } \\
\text { own ideas and develop them into complete } \\
\text { both sets of respondents shared dissimilar }\end{array}$ & $\begin{array}{l}\text { Id that } \\
\text { s place } \\
31.8 \% \text { ) } \\
\text { ow that } \\
\text { ers and } \\
\text { vity in } \\
\text { eachers } \\
\text { shared } \\
\text { are of } \\
\text { while } 8 \\
\text { eachers } \\
18.2 \% \text { ) } \\
\text { th their } \\
\text { works, }\end{array}$ & & $\begin{array}{l}\text { ers, w } \\
\text { reed. } \\
\text { that pl } \\
\text { ong ru } \\
\text { for hea } \\
\text { lusion } \\
\text { study } \\
\text { ing cr } \\
\text { Coast } \\
\text { lis stu } \\
\text { ive art } \\
\text { re. Thi } \\
\text { reativit }\end{array}$ & all & $\begin{array}{l}\text { th he } \\
\text { heir s } \\
\text { eprese } \\
\text { and } 8 \\
\text { the } \\
\text { lis. } \\
\text { teach } \\
\text { new } \\
\text { possi } \\
\text { orcem } \\
\text { pup }\end{array}$ & $\begin{array}{l}\text { tea } \\
\text { ools } \\
\mathrm{s} \text { th } \\
4 \text { pe } \\
\text { rforr } \\
\text { inder } \\
\text { res } \\
\text { owle } \\
\text { har }\end{array}$ & $\begin{array}{l}\text { l, } 10 \\
\text { s and } \\
\text { form } b \\
\text { ews of } \\
\text { nt of te } \\
\text { ce of } \\
\text { ten sch } \\
\text { her co } \\
\text { the ne } \\
\text { pupils } \\
\text { h the p } \\
\text { e deve } \\
\text { ough }\end{array}$ & $\begin{array}{l}5.5 \%) \\
\text { achers } \\
\text { ter in } \\
0 \text { per } \\
\text { chers. } \\
\text { achers } \\
\text { ols in } \\
\text { luded } \\
\text { essary } \\
\text { eed to } \\
\text { vision } \\
\text { pment } \\
\text { KG }\end{array}$ \\
\hline
\end{tabular}


and learning materials, the materials are not in suitable conditions. This notwithstanding effective teaching of practical creative art lesson takes place in the KG schools in the Metropolis. This is seen in the ability of pupils coming out with their own ideas and develops them into complete works. Thus, pupils in KG can be helped to develop their potentials in the creative arts when the necessary activities and inputs are provided.

\section{Recommendation}

1. It was recommended that teaching and learning materials must be kept in a suitable condition in the K.G.

\section{References}

[1] Appiah-Ofori, E. C. (2000). Pre-vocational Skill Basic Knowledge and Methodology. Cape Coast: Catholic Mission Press.

[2] Amenuke, S. K., Dogbe, B. K., Asare, F. D. K., Ayiku, R. K. \& Baffoe, A. (1997).General Knowledge in Art. London: Evans Brothers Ltd.

[3] Ary, D., Jacobs, L. C. \& Ravazieh, A. (1990). Introduction to Research in Education ( $4^{\text {th }} \mathrm{ed}$.) New York: Holt, Rinehart and Winston Inc.

[4] Babbie, E. (1996). Survey Research Method (2 ${ }^{\text {nd }}$ ed.) New Delhi: Prentice Hall of India.

[5] Bame, K. N. (1991). Teacher Motivation and Retention in Ghana. Accra: Ghana Universities Press.

[6] Beittel, K. R. (1972). Mind and Context in the Art of Drawing. New York: Holt, Rinehart and Wiston.

[7] Beittel, K. R. (1973). Alternatives for Art Education Research Dubuque, IA: Willima C Brown.

[8] Chapman, L. (1978). Approaches to Art in Education. New York: Harcourt Brace Jovanovich.

[9] Damico, M. (2007). Daminco defies kindergarten teaching trend. Lantern. Retrieved: July 10, 2013. Website:http://ealumnus.uwlax. edu/w...1/07/MattD amicomain web1

[10] Davis, I. (1997). The ' $U$ ' and the Wheel of ' $C$ ': Development and Devaluation of Graphic Symbolization and Cognitive Approach at Harvard Project Zero. Reston, VA: The National Art Education Association.

[11] Duncum, P. (1997). Subjects and Themes in Children's Unsolicited Drawing and Gender Socialization. Child Development in Art. VA: The National Art Education Association

[12] Eisner, E. W. (1972). Educating Artist Vision. London: Macmillan Publishing.
[13] Essa, E. L. (2003). Introduction to Early Childhood Education. Clifton Park, New York:Thompson (Delmar Learning).

[14] Fraenkel, J. R. \& Wallen, N. E. (1993). How to Design and Evaluate Research in Education $\left(5^{\text {th }}\right.$ Ed.). New York: McGraw. Hill Companies Inc.

[15] Gaitskell, D. G., Hurwitz, Al \& Day, M., (1982). Children and their Art: Methods for the Elementary School. (4 ${ }^{\text {th }}$ ed.) New York: Harcourt Bruce Jovanovich Inc. P. 6

[16] Gardener, H. (1993). Creating Minds, New York: Basic Books.

[17] Gay, L. R. (1987). Educational Research: Competence for Analysis and Application. $\left(3^{\text {rd }}\right.$ ed.). Ohio: Merrill Publishing Company.

[18] Golomb, C. (1997). Representational Concepts in Clay: The Development of Sculpture.

[19] Reston, VA: The National Art Education Association.

[20] Hama, J. \& Duodou, F. (2003). The School Curriculum, a Tool for Education and National Development: Yamens Press Ltd.

[21] Healy, J. M. (1994). Your Child Growing Minds. New York: Duobleday.

[22] Kellogg, R. (1970). Analyzing Children's Art. Mountain View, CA: Mayfield Publishing Company.

[23] Jameson, K. (1968). Pre-school and Infant Art. London: Studio Vista Ltd.

[24] Lasky, L. \& Mukerji-Bergson, R. (1995). Art: $B$ for young children. Washington D C: National Association for the Education of Young Children.

[25] Lay-Dopyera, M. \& Dopyera, J. (1992). Becoming a Teacher of Young Children. New York: McGraw-Hill.

[26] Lowenfeld, V. \& Brittain, W. L. (1970).Creative and Mental Growth. London: Macmillan Company. Larson, L. R. \& Yocom, R. D. (1951).

[27] Measurement and Evaluation in Physical Health and Recreation: St Louis C. V. Mosby Company.

[28] Mayesky, M. (2002). Creative Activities for Young Children. Albany: Delmar/Thompson Learning.

[29] Moser, C. A. \& Kalton, G. (1986). Survey Methods in Social Investigation. London:Heinemann.

[30] Murphy, R. J. L. \& Torrance, E. P. (1992). Educational Assessment. New York: Fulner Press. p.38 
[31] Nancino-Brown, R. (1982). Curriculum and Instruction: An Instruction to Methods of Teaching. New York: MacMillan Publishers.

[32] Ocvirk, O. G., Bone, R., Stinson, R. \& Wigg, P. (1962). Art: Fundamentals, Theory and Practice: W. M. C. Brown Company, USA. p. 2

[33] Ofori, S. S. (2003). Classroom Without Walls: Using Collaboration Activities Between Indigenous Potters of Vame and U.E.W Student of Ceramics Education as Instructional tool. Unpublished Action Research report: U.E.W.

[34] Ornstein, A. C. (1995). Strategies for Effective Teaching (2nd Ed.) Chicago: Brown and Benchmark . pp. 406,407

[35] Owusu, D. D. (1994). Evaluation of Art Education Diploma Programme in the College of Art, UST, Kumasi, Ghana. pp. 7, 8

[36] Quayson, S. A. (2006). Evaluation of Visual Art Programme in the Western Region of Ghana. Kumasi: UST, Ghana.

[37] Quansah, K. B. (1997): Monitoring Standards in Basic Education using CriterionReferenced Tests. Accra: Institute for Economic Affairs Round Table Discussion Paper: July 18, 1997 /Ghana Education Service.

[38] Seifert, K. L. \& Hoffnung, J. R. (1994). Child and Adolescent Development $\left(2^{\text {nd }}\right.$ ed.).Boston: Houghton Mifflin Company.

[39] Stanfield, N. F. (1976). A Handbook of Art Teaching in Tropical Schools. London: Evans Brothers.

[40] Szekely, G. (1988). Encouraging Creativity in Art Lesson. New York: Teacher College, Columbia University.

[41] Tamakloe, E. K. (1997). An Evaluation of the National Conference on Teacher Education 1986: Ghana University Press, Accra, Ghana. p. 8.

[42] Thompson, C. M. (1995). The Visual Arts and Early Childhood Learning. VA: The National Art Education Association.

[43] Thunder-McGuire, S. (1994). An Inner Critic in Children's Artistic Bookmaking.Visual Arts Research, 20(2), 51-61.

[44] Uzoagba, I. N. (2000). Understanding Art in General Education. Nigeria: Rex Charles \& Patrick Ltd. pp. 37, 56

[45] Vygotsky, L. S. (1978). Minds in Society. M. Cole, V. John-Steiner, S. Scribner, \& E. Souberman, (Eds. \& Trans.). Cambridge, MA: Harvard University Press.

[46] Wachowiak, F. (1995). Emphasis on Art (4 ${ }^{\text {th }}$ ed) New York: Harper Collins Publisher
[47] Zurmuehlen, M. (1990). Studio Art: Praxis, Symbol Presence. Reston, VA: The National Art Education Association. 